\title{
PENGARUH KONSENTRASI LARUTAN URIN SAPI SEBAGAI MEDIA PENYIRAMAN DAN PUPUK ORGANIK TERHADAP PERSENTASE PERKECAMBAHAN, PERSENTASE KECAMBAH NORMAL DAN PRODUKSI HIJAUAN SEGAR PADA HIDROPONIK FODDER JAGUNG (Zea mays)
}

\author{
Tri Ida Wahyu Kustyorini*; Aju Tjatur Nugroho; Dimas Zulfikar Hanif \\ Fakultas Peternakan \\ Universitas Kanjuruhan Malang \\ triida@unikama.ac.id
}

\begin{abstract}
ABSTRAK
Tujuan penelitian ini adalah untuk mengetahui pengaruh konsentrasi larutan urin sapi yang berbeda terhadap persentase perkecambahan, persentase kecambah normal dan produksi hijauan segar pada hidroponik fodder jagung (Zea mays). Materi yang digunakan dalam penelitian ini adalah jagung kuning sebanyak 6.250 biji, urin dan air. Metode penelitian yang digunakan adalah percobaan lapang dengan menggunakan Rancangan Acak Lengkap (RAL) dengan 5 perlakuan dan 5 ulangan. Adapun perlakuan yang di gunakan adalah P0 (100ml air), P1 (5\% urin), P2 (10\% urin), P3 (15\% urin), P4 (20\% urin). Variabel yang diamati dalam penelitian ini adalah persentase perkecambahan, persentase kecambah normal dan produksi hijauan segar. Data yang diperoleh dianalisis dengan menggunakan analisis sidik ragam (ANOVA), apabila terdapat perbedaan dilakukan uji lanjut dengan menggunakan Uji BNT (Beda Nyata Terkecil).Berdasarkan hasil penelitian, menunjukkan bahwa produktivitas fodder jagung (Zea mays) dengan perlakuan penyiraman menngunakan konsentrasi larutan urin sapi yang berbeda memberi pengaruh yang sangat nyata $(\mathrm{P}<0,01)$ terhadap persentase perkecambahan, persentase kecambah normal dan produksi hijauan segar. Persentase perkecambahan tertinggi pada P1 (70,48\%), persentase kecambah normal tertinggi P1 $(94,63 \%)$ dan produksi hijauan segar tertinggi pada P1 (138 gram). Berdasarkan hasil penelitian dapat disimpulkan bahwa penggunaan konsentrasi larutan urin 5\% sebagai media penyiraman dan pupuk organik memberikan nilai terbaik terhadap persentase perkecambahan, persentase kecambah normal dan hijauan segar pada hidroponik fodder jagung (Zea mays).
\end{abstract}

Kata Kunci: Urin, Sapi, Konsentrasi, Jagung, Fodder Jagung.

\begin{abstract}
The aim of this research were to know of the effect of different concentrations of cow urine solution on the effect of urine cow solution concentration for watering media and organic fertilizer on percentage of gemination, percentage normal germination and plant production on corn fodder (Zea mays) with a hydroponic system of corn fodder (zea mays) with hydroponic systems. The material of this research were corn, urine and water. The method used was experimental field using Completely Randomized Design (CDR) with 5 treatmens and 5 replications. The treatment used is $\mathrm{P} 0$ ( $0 \%$ urine solution), $\mathrm{P} 1$ ( $5 \%$ urine solution), $\mathrm{P} 2$ (10\% urine solution), P3 (15\% urine solution), P3 (20\% urine solution). The variables observed in this study were Percentage of Germination, Percentage of Normal Germination and Plant Production. Based on the results of the study, it shown that watering treatment using different concentrations of cow solution had a very significant effect $(\mathrm{P}<0.01)$ on germination percentage, normal germination percentage and plant production. The highest percentage of germination was P1 $(70.48 \%)$, the highest percentage of normal germination was P1 (94.63\%) and the highest plant production was P1 (138 grams). Based on the results of the study it can be concluded that the treatment by giving $5 \%$ urine cow solution concentration for watering media and organic give the best value to fertilizer on percentage of gemination, percentage normal germination and plant production on corn fodder (Zea mays) with a hydroponic system.
\end{abstract}

Keyword : Urine, Cow, Concentration, Corn, Corn Fodder 


\section{Pendahuluan}

Dengan Semakin banyaknya jumlah populasi ternak, maka semakin tinggi pula kebutuhan pakan hijauan yang diperlukan. Maka dari itu, ketersediaannya harus ada secara terus-menerus untuk mencukupi kebutuhan ternak ruminansia tersebut. Pengadaan pakan hijauan ternak harus terus dikembangkan untuk menjaga kontinyuitas dan kualitas produksi dari ternak yang dipelihara. Akan tetapi, pengembangan pakan hijauan ternak hanya memungkinkan jika dilaksanakan di daerah-daerah yang masih jarang penduduknya. Fodder jagung hidroponik dapat dijadikan solusi untuk penyediaan hijauan bagi ternak ruminansia, karena dengan sistem ini penanaman dapat dilakukan sepanjang tahun tanpa dipengaruhi musim (Prihartini, 2014).

Jagung (Zea mays) merupakan salah satu tanaman pangan dunia yang terpenting, selain gandum dan padi. Jagung merupakan salah satu serealia yang strategis dan bernilai ekonomi serta mempunyai peluang untuk dikembangkan karena kedudukannya sebagai sumber utama karbohidrat dan protein setelah beras dan juga sebagai sumber pakan (Purwanto, 2008). Produktivitas fodder jagung dipengaruhi oleh faktor internal (hormon dan genetik) dan faktor eksternal diantarannya adalah iklim, ketersediaan unsur hara, dan kadar air.

Usaha yang dilakukan untuk memperbaiki kesuburan tanah adalah dengan melakukan pemupukan menggunakan pupuk organik. Kandungan unsur hara dalam pupuk kandang tidak terlalu tinggi, tetapi jenis pupuk ini mempunyai lain yaitu dapat memperbaiki sifat - sifat fisik tanah seperti permeabilitas tanah, porositas tanah, struktur tanah, daya menahan air dan kation - kation tanah. (Roidah, 2013)

Urin sapi adalah limbah yang berbentuk cairan atau berada dalam fase cair (air seni atau urin) dapat merangsang pertumbuhan akar karena mengandung auksin. Auksin merupakan salah satu zat pengatur tumbuh (ZPT) yang berperan penting pada proses pertumbuhan dan perkembangan suatu tanaman, Budianto, dkk (2013). Kadar zat pengatur tumbuh (ZPT) pada urin sapi memiliki kandungan auksin sebanyak $34 \mathrm{ppm}$ dan giberellin sebanyak 268 ppm setelah disimpan selama 7 hari menurut (Nasution, 2014).

Urin sapi dapat menjadi alternatif saat kelangkaan pupuk urea terjadi. Urin sapi yang biasanya hanya menjadi limbah peternakan akan lebih berguna bila dimanfaatkan sebagai pupuk cair untuk tanaman. Urine pada ternak sapi terdiri dari air 92\%, nitrogen $1,00 \%$, fosfor $0,2 \%$, dan kalium $0,35 \%$ (Sutedjo, 2010). Kandungan nitrogen yang tinggi pada urin sapi, menjadikan urin sapi cocok digunakan sebagai pupuk cair yang dapat menyediakan unsur hara nitrogen bagi tanaman. Di dalam urin sapi juga tergandung unsur 
hara fosfor yang berguna untuk pembentukan bunga dan buah, serta unsur hara Kalium yang berfungsi untuk meningkatkan proses fotosintesis, aktivator bermacam sistem enzim, memperkuat perakaran, dan meningkatkan ketahanan tanaman terhadap penyakit.

Proses penyiraman tanaman merupakan salah satu aspek yang memegang peranan penting dalam tumbuh kembang tanaman, sehingga perlu dilakukan monitoring dalam proses penyiraman untuk menjaga agar penyiraman berjalan dengan optimal. Ada beberapa faktor yang harus diperhatikan dalam melakukan monitoring penyiraman tanaman, diantaranya adalah kelembaban tanah dan suhu udara (Paiman dkk, 2014).

\section{Materi dan Metode}

Sumber data penelitian merupakan faktor penting yang menjadi pertimbangan yang menentukan metode pengumpulan data. Jenis data yang akan digunakan dalam penelitian ini data primer dan data sekunder merupakan data penelitian yang secara langsung dari sumber asli atau tidak melalui perantara. Data primer adalah data yang diperoleh peneliti langsung dari hasil lab yang diteliti oleh peneliti untuk analisis deskriptif dalam hal ini data Konsentrasi Larutan Urin Sapi sebagai Media Penyiraman dan Pupuk Organik melalui teknik pratikum dan Dokumentasi meliputi data cara memilih bibit jagung yang baik, lama perndaman, jumlah biji jagung, menyampurkan larutan urin, perhitungan produksi hijauan. Data sekunder merupakan sumber data yang diperoleh secara tidak langsung seperti data dari literatur, sumber-sumber dari pustaka yang ada dan data pendukung lainnya.

Variabel adalah segala sesuatu yang dapat diberi berbagai macam nilai (Indriantoro, 2009). Variabel terikat (dependen) yang digunakan dalam penelitian ini adalah persentase perkecambahan, persentase kecambah normal dan produksi hijauan segar pada hidroponik fodder jagung (zea mays), sedangkan variabel bebas (independen) adalah pengaruh konsentrasi larutan urin sapi sebagai media penyiraman dan pupuk organik.

\section{Hasil Dan Pembahasan}

Berdasarkan hasil penelitian penyiraman jagung dengan menggunakan larutan urin ternak sapi menunjukan bahwa terdapat pengaruh yang sangat nyata terhadap persentase perkecambahan, persentase kecambah normal dan produksi hijauan segar.

\section{Persentase Perkecambahan}

Berdasarkan hasil analisis sidik ragam menunjukkan bahwa konsentrasi larutan urin ternak sapi yang berbeda sebagai media penyiraman dan pupuk organik memberikan 
pengaruh yang sangat nyata $(\mathrm{P}<0,01)$ terhadap persentase perkecambahan fodder jagung (Zea mays). Rata-rata persentase perkecambahan disajikan pada tabel 1.

Tabel 1. Hasil Rataan Persentase Perkecambahan

\begin{tabular}{lc}
\hline Perlakuan & Rataan $(\%)$ \\
\hline P0 & $56,56 \pm 12,41^{\mathrm{a}}$ \\
P1 & $70,48 \pm 11,36^{\mathrm{b}}$ \\
P2 & $50,16 \pm 10,98^{\mathrm{a}}$ \\
P3 & $47,04 \pm 10,90^{\mathrm{a}}$ \\
P4 & $46,32 \pm 9,26^{\mathrm{a}}$ \\
\hline \multicolumn{2}{l}{ Keterangan: ${ }^{\mathrm{a}-\mathrm{b}}$ Notasi yang berbeda pada kolom yang sama menunjukkan perbedaan yang sangat } \\
& nyata $(\mathrm{P}<0,01)$
\end{tabular}

Berdasarkan dengan perlakuan menggunakan konsentrasi larutan urin ternak sapi sebagai media penyiraman dan pupuk organik menunjukkan bahwa larutan urin ternak sapi memberikan pengaruh yang sangat nyata $(\mathrm{P}<0,01)$ terhadap persentase perkecambahan. Persentase perkecambahan tertinggi terdapat pada perlakuan (P1) yang menggunakan konsentrasi larutan urin sapi sebanyak 5\% dengan nilai 70,48\% dan persentase perkecambahan terendah pada perlakuan (P4) yang menggunakan konsentrasi larutan urin sapi sebanyak $20 \%$ dengan nilai $46,32 \%$.

Sarah dkk, (2016) menyatakan bahwa keberhasilan presentase perkecambahan mencapai $80 \%$ hasil tersebut dapat menjadi acuan untuk melakukan penanaman pada fodder jagung. Hasil penelitian yang saya teliti di lapangan menghasilkan 70,48\% dan faktor yang mempengaruhi persentase perkecambahan tidak sesuai standar adalah suhu, cahaya dan kandungan urin sapi.

\section{Persentase Kecambah Normal}

Berdasarkan hasil analisis sidik ragam menunjukan bahwa perlakuan penyiraman jagung dengan menggunakan konsentrasi larutan urin ternak sapi yang berbeda memberikan pengaruh yang sangat nyata $(\mathrm{P}<0,01)$ terhadap persentase perkecambahan normal. berdasarkan uji bnt disajikan pada tabel 2 .

Tabel 2. Hasil Persentase Kecambah Normal

\begin{tabular}{lr}
\hline Perlakuan & Rataan $(\%)$ \\
\hline P0 & $83,8 \pm 7,99^{\mathrm{a}}$ \\
P1 & $94,63 \pm 7,76^{\mathrm{c}}$ \\
P2 & $87,03 \pm 9,97^{\mathrm{b}}$ \\
P3 & $85,71 \pm 9,57^{\mathrm{b}}$ \\
P4 & $75,96 \pm 5,47^{\mathrm{a}}$ \\
\hline \multicolumn{2}{l}{ Keterangan: ${ }^{\mathrm{ac}}$ Notasi yang berbeda pada kolom yang sama menunjukkan perbedaan yang sangat } \\
$\quad$ nyata $(\mathrm{P}<0,01)$
\end{tabular}


Berdasarkan hasil uji BNT 1\% dengan perlakuan menggunakan konsentrasi larutan urin ternak sapi sebagai media penyiraman dan pupuk organik menunjukkan bahwa larutan urin ternak sapi memberikan pengaruh yang sangat nyata $(\mathrm{P}<0,01)$ terhadap persentase perkecambahan normal dengan nilai tertinggi 94,63\% (P1) menggunakan konsentrasi larutan sebanyak 5\% dan persentase perkecambahan normal yang terendah adalah perlakuan (P4) dengan menggunakan konsentrasi larutan sebanyak $20 \%$.

Hermawan (2011), standar kecambah normal 70\% dan menyatakan bahwa jika penyiraman dilakukan tidak sesuai maka pertumbuhan benih tersebut akan bersifat merusak atau penghambat pertumbuhan. Hasil penelitian yang saya teliti di lapangan menghasilkan 94,63\% dan hasil dari persentase tersebut menyatakan bahwa sudah memenuhi standar yang di butuhkan untuk persentase kecambah normal.

\section{Produksi Segar}

Berdasarkan hasil analisis sidik ragam menunjukan bahwa perlakuan penyiraman jagung dengan menggunakan konsentrasi larutan urin ternak sapi yang berbeda memberikan pengaruh yang sangat nyata $(\mathrm{P}<0,01)$ terhadap produksi segar. Rataan produksi hijauan segar disajikan pada tabel 3.

Tabel 3. Hasil Rataan Produksi Hijauan Segar

\begin{tabular}{lr}
\hline Perlakuan & Rataan \\
\hline P0 & $124 \pm 13,30^{\mathrm{b}}$ \\
P1 & $138 \pm 6,80^{\mathrm{c}}$ \\
P2 & $118 \pm 21,45^{\mathrm{a}}$ \\
P3 & $110,6 \pm 22,20^{\mathrm{a}}$ \\
P4 & $108,4 \pm 13,66^{\mathrm{a}}$ \\
\hline Keterangan: ${ }^{\mathrm{a}-\mathrm{c}}$ Notasi yang berbeda pada kolom yang sama menunjukkan perbedaan yang sangat \\
& nyata $(\mathrm{P}<0,01)$
\end{tabular}

Berdasarkan hasil uji BNT 1\% menunjukkan bahwa perlakuan faktor konsentrasi larutan urin ternak yang berbeda memberikan pengaruh yang sangat nyata terhadap produksi segar. Rataan tertinggi terdapat pada perlakuan menggunakan konsentrasi $5 \%$ dengan nilai $138 \mathrm{~g}$ yang berbeda sangat nyata dengan perlakuan mengunakan konsentrasi larutan urin sapi $10 \%, 15 \%$ dan $20 \%$.

Produksi fodder jagung yang dihasilkan dari biji jagung sebanyak 713 gram menghasilkan sekitar 2 kali lipat hijauan segar dengan umur panen 13 hari (Prihartini, 2014). Menurut (Djajanegara et al. 1998) mengatakan bahwa faktor yang sangat mempengaruhi pertumbuhan tanaman adalah ketersedian air, jenis perendamaan, lama 
perendaman dan pemupukan pada media. Neil dan Rollinson (1974) menyatakan bahwa standart produksi segar aalah $41 \%$.

\section{Kesimpulan}

Berdasarkan hasil yang disimpulkan bahwa perlakuan penyiraman pada biji jagung dengan konsentrasi larutan urin sapi yang berbeda. Selama 14 hari berpengaruh sangat nyata, dengan menambahkan 5\% Berdasarkan hasil penelitian dapat disimpulkan bahwa penggunaan konsentrasi larutan urin 5\% sebagai media penyiraman dan pupuk organik memberikan nilai terbaik terhadap persentase perkecambahan, persentase kecambah normal dan hijauan segar pada hidroponik fodder jagung (Zea mays).

\section{Ucapan Terimakasih}

Ucapan terimakasih kepada Laboratorium Fakultas Peternakan Universitas Kanjuruhan Malang yang sudah memberikan izin terhadap pelaksanaan penelitian.

\section{DAFTAR RUJUKAN}

Bambang Supomo dan Nur Indriantoro, 2002. Metodologi Penelitian Bisnis, Cetakan Kedua, Yogyakarta, Penerbit BFEE UGM.

Djajanegara et al, 1998. Ketersedian Air, Jenis Perendaman, Lama Perendaman Dan Pemupukan Pada Media Sangat Berpengaruh Terhadap Produksi Bahan Kering.IPB. Bogor.

Hermawan (2011). Pengaruh Penyiraman Terhadap Persentase Perkecambahaan jagung. Skripsi. Jurusan Pertanian, Fakultas Pertanian, Universitas Patimura Ambon.

Prihartini, 2014. Fodder jagung hidroponik sebagai solusi penyediaan hijauan bagi ternak ruminansia dan sistem penanaman dilakukan sepanjang tahun. Bogor (ID): Institut Pertanian Bogor.

Istiqomah N, Mahdiannoor, dan Norasiah, 2017. Efektivitas Pemberian ZPT Dan Kombinasi Media Pada Perbanyakan Tanaman Lada Secara Stek. Sekolah Tinggi Ilmu Pertanian Amuntai Program Studi Agroteknologi.

Nasution. 2014. Percepatan Perkecambahan dan Pertumbuhan Bibit Biwa (Eriobotrya japonica lindl.) Akibat Perendaman Pada Urine Hewan dan Pemotongan Benih. Skripsi. Medan: F. Pertanian USU

Neil AJ and Rollinson D.H.L. 1974. The Requirement and Availability of Livestock Feed In Indonesia. Working Paper. Jakarta. 
Paiman, Yudono, A., Sunarminto, B. H., Dan Indradewa, D., 2014. Pengaruh Karakter Agronomis Dan Fisiologis Terhadap Hasil Pada Cabai Merah (Capsicum annuum L). AgroUPY, 6(1), 1-13.

Purwanto R J, Agustina K, Yursida 2014. Tanggap Tanaman Jagung terhadap Aplikasi POC Urin Sapi dan Pupuk Anorganik di Lahan Pasang Surut Tipe Luapan C. Fakultas Pertanian Universitas IBA.

Roidah I S, 2013. Manfaat Menggunakan Pupuk Organik Untuk Kesuburan Tanah. Fakultas Pertanian Universitas Tulungagung

Sarah, Hafnati Rahmatan, Supriatno, 2016. Pengaruh Pemberian Berbagai Konsentrasi Urin Kambing Yang Difermentasi Terhadap Pertumbuhan Vegetatif Lada (Piper nigrum L.). Fakultas Keguruan Dan Ilmu Pendidikan Prodi Biologi Unsyiah.

Sutedjo, M. M, 2010. Pupuk Dan Cara Pemupukan. Rineka Cipta. Jakarta. 